\title{
KARAKTERISTIK YANG MEMPENGARUHI MOBILISASI DINI PADA IBU NIFAS POST SECTIO CAESAREA \\ (Di Ruang Merpati RSUD Dr. Soetomo Surabaya )
}

\author{
Yuli Setyowati $^{1}$, Supartini ${ }^{2}$ \\ 1. Mahasiswi Prodi D-III Kebidanan Universitas PGRI Adi Buana Surabaya \\ 2. Tenaga Pengajar Prodi D-III Kebidanan Universitas PGRI Adi Buana Surabaya
}

\begin{abstract}
ABSTRAK
Mobilisasi dini ialah kebijaksanaan untuk selekas mungkin membimbing penderita keluar dari tempat tidurnya dan membimbingnya selekas mungkin untuk berjalan. Berdasarkan data yang didapatkan di RSUD Dr. Soetomo Surabaya tahun 2010 jumlah pasien yang mengalami tindakan Sectio Caesarea sejumlah 798 pasien, sedangkan pada tahun 2011 berjumlah 983 pasien mengalami peningkatan sebesar $2,3 \%$. Tujuan dilakukan penelitian untuk mengetahui karakteristik yang mempengaruhi mobilisasi dini pada ibu nifas Post Sectio Caesarea di Ruang Merpati RSUD Dr. Soetomo Surabaya. Penelitian ini merupakan jenis penelitian deskriptif dengan pendekatan cross sectional. Populasi dalam penelitian ini adalah semua ibu nifas dengan Sectio Caesarea yang dirawat di Ruang Merpati RSUD Dr. Soetomo Surabaya sejumlah 50 pasien. Cara pengambilan sampel dalam penelitian ini adalah quota sampling. Sampel dalam penelitiansejumlah 30ibu nifas post Sectio Caesarea dengan menggunakan kuesioner dan observasi.Berdasarkan hasil penelitian yang telah dilakukan diperoleh hasil bahwa dari 30 responden mobilisasi dini dilakukan cenderung dengan baik pada ibu dengan tingkat pendidikan SD sebesar $87,5 \%$, sedangkan berdasarkan umur mobilisasi dini cenderung dilakukan dengan baik pada umur $>35$ tahun, sebesar $66,7 \%$, dan berdasarkan paritas multipara sebesar 71,4\%.Karakteristik yang Mempengaruhi Mobilisasi Dini pada Ibu Nifas Post Sectio Caesarea di Ruang Merpati RSUD Dr. Soetomo Surabaya 2012 ibu dapat melakukan mobilisasi dini post sectio caesarea yang dilatar belakangi tingkat pendidikan $\mathrm{SD}$, umur $>35$ tahun, multipara, sedangkan pada ibu primipara dan grandemulti mobilisasinya lebih banyak mengalami gangguan.
\end{abstract}

Kata Kunci : Ibu Nifas Post Sectio Caesarea, mobilisasi dini

\section{PENDAHULUAN}

Upaya pembangunan di bidang kesehatan yang sedang dilakukan secara bertahap dan berkesinambungan selama ini pada dasarnya untuk mempercepat tercapainya tingkat kesejahteraan. Salah satu program yang bertujuan untuk menurunkan angka kematian ibu (AKI) dan angka kematian bayi (AKB) masih merupakan kendala besar di negara berkembang seperti Indonesia (Himatusujanah, 2008).

Sectio Caesarea adalah suatu tindakan untuk melahirkan bayi dengan berat diatas 500 gram, melalui sayatan pada dinding uterus yang masih utuh (intact). Istilah dalam sectio caesarea adalah primer, sekunder, ulang, histerektomi. Penyebab dilakukan sectio caesarea diantaranya faktor janin, faktor ibu, riwayat persalinan sebelum dioperasi, faktor hambatan jalan lahir, kelainan kontraksi rahim, ketuban pecah dini, rasa takut persalinan. Indikasi Sectio Caesarea antara lain adalah disproporsi kepala panggul (CPD), disfungsi uterus, distosia, janin besar, gawat janin, kelainan letak, eklampsia, hipertensi pernah Sectio Caesarea sebelumnya, persalinan lama, ruptura uteri iminens, perdarahan antepartum (Sarwono, 2006).

Di Amerika Serikat antara tahun 1965 sampai 1988, angka Sectio 
Caesareakeseluruhan setiap tahun meningkat secara progresif dari $4,5 \%$ semua persalinan sampai hampir 25\% (United State Public Health Service, 1991). Sebagian besar peningkatan ini berlangsung pada tahun 1970-an sampai awal 1980-an dan terjadi di seluruh negara barat. Menurut Belizan dkk (1999) di Amerika Serikat telah merekomendasikan dua patokan pada tahun 2010, angka sectio caesarea sebesar $15,5 \%$ pada wanita nulipara dengan usia kehamilan 37 minggu atau lebih dengan janin tunggal presentasi kepala, angkakelahiran pervaginam dengan riwayat Sectio Caesarea sebesar $37 \%$ pada wanita dengan usia kehamilan 37 minggu atau lebih dengan janin tunggal presentasi kepala dan riwayat satu kali Sectio Caesarea (Cunningham, dkk., 2006).

Sementara di Indonesia terjadi peningkatan Sectio Caesarea dimana tahun 2000 sebesar 47,22\%, tahun 2001 sebesar 45,19\%, tahun 2002 sebesar 47,13\%, tahun 2003 sebesar 46,87\%, tahun 2004 sebesar $53,22 \%$, tahun 2005 sebesar $51,59 \%$, tahun 2006 sebesar 53,68\% (Himatusujanah, 2008).

Berdasarkan data yang didapatkan di RSUD Dr. Soetomo Surabaya tahun 2010 jumlah pasien yang mengalami tindakan Sectio Caesarea sejumlah 798 pasien, sedangkan pada tahun 2011 berjumlah 983 pasien mengalami peningkatan sebesar $2,3 \%$.

Dalam meningkatkan mutu pelayanan dan menyelamatkan jiwa ibu nifas maka perlu pemberian prioritas pelayanan kesehatan yang komprehensif yang bersifat terpadu dan berkesinambungan dengan menggunakan metode asuhan kebidanan yang meliputi tahaptahapan pengkajian, perencanaan, pelaksanaan tindakan dan evaluasi dengan memandang klien sebagai satu kesatuan yang utuh secara biopsiko-sosial-spiritual dan kultural. Didalam pelaksanaan pelayanan kebidanan perlu keterlibatan klien dan keluarga sehingga keberhasilan bersama akan menimbulkan persamaan persepsi antara petugas kesehatan atau bidan, klien, keluarga klien dengan harapan klien dan keluarganya mampu memahami kerjasama yang baik untuk upaya penyembuhan dan mengatasi masalah yang ada.

Mobilisasi dini adalah pergerakan yang dilakukan sedini mungkin ditempat tidur dengan melatih bagian - bagian tubuh untuk melakukan peregangan (Sulaiman, 2000). Mobilisasi dini segera tahap demi tahap sangat berguna untuk membantu jalannya penyembuhan luka pada ibu post Sectio Caesarea. Kemajuan mobilisasi dini tergantung pada jenis operasi yang dilakukan dan komplikasi yang mungkin dijumpai. Apabila menggunakan epidural atau spinal block, mobilisasi dini dimulai dengan tubuh bagian bawah dapat merasakan sehingga dapat menggoyangkan kaki, selanjutnya mulai miring ke kanan dan ke kiri dapat dimulai sejak 6-10 jam secara berturut-turut duduk, berjalan disekitar tempat tidur dan mulai berjalan dalam jarak pendek (Chrissie Gallagher Mundi, 2004).

Faktor-faktor yang mempengaruhi mobilisasi dini antara lain faktor intern : jenis persalinan khususnya pada ibu yang post Sectio Caesarea, takut jahitan lepas bila bergerak, kelelahan saat mengalami partus lama, cidera yang dialami sebelum persalinan akibat fraktur tulang belakang, keadaan umum dipengaruhi oleh penyakit penyerta ibu, persepsi nyeri tiap pasien berbeda, motivasi untuk melakukan mobilisasi dini, tindakan dengan anestesi, gaya hidup, emosi; faktor ekstern: dukungan suami, keluarga, kebudayaan yang melarang bergerak dan kaki harus lurus, sosial ekonomi, pelayanan yang diberikan petugas, individu senantiasa menyesuaikan dengan lingkungan menurut kebutuhannya. Faktor karakteristik : tingkat pendidikan mempengaruhi pemahaman yang diberikan petugas kesehatan, umur yang muda cenderung malu atau menarik diri, ibu bekerja terbiasa dituntut menyelesaikan tugasnya, paritas yang lebih banyak ibu akan segera melakukan mobilisasi dini karena harus merawat dan memberikan perhatian kepada anak yang lain (Rustam, 1998).

Upaya yang dapat dilakukan oleh bidan sebagai tenaga medis yang berhubungan langsung dengan ibu adalah dengan memberikan penyuluhan tentang cara mengatasi 
nyeri jahitan post Sectio Caesarea dan perawatan jahitan post Sectio Caesarea. Selama perawatan di ruang merpati RSUD dr. Soetomo Surabaya ibu diajarkan untuk mobilisasi dini, memberikan minyak kayu putih, memakai gurita untuk rasa nyaman, dan mengkonsumsi obat obatan sesuai dengan anjuran dokter.

Berdasarkan pengamatan yang dilakukan pada tanggal 1 februari sampai 5 Maret 2012 di RSUD dr. Soetomo tindakan Sectio Caesarea sejumlah 119 pasien. Petugas kesehatan telah memberikan penyuluhan dan motivasi kepada ibu nifas Post Sectio Caesarea dari 119 pasien sebagian ibu melakukan mobilisasi dini dengan cepat, sebagian lagi lambat dan sulit atau membutuhkan waktu yang lebih lama sehingga petugas kesehatan harus memberikan perhatian dan pengamatan khusus pada pasien tersebut. Berdasarkan fenomena tersebut peneliti merasa tertarik untuk melakukan penelitian tentang karakteristik yang mempengaruhi mobilisasi dini pada ibu nifas Post Sectio Caesarea di Ruang Merpati RSUD dr. Soetomo Surabaya.

Rumusan Masalah dalam penelitian ini adalah karakteristik apakah yang mempengaruhi mobilisasi dini pada ibu nifas Post Sectio Caesarea di Ruang Merpati RSUD Dr. Soetomo Surabaya?Tujuan Umum penelitian adalah mengetahui karakteristik yang mempengaruhi mobilisasi dini pada ibu nifas Post Sectio Caesarea di Ruang Merpati RSUD Dr. Soetomo Surabaya.Tujuan adalah:1)mengidentifikasi Khususnya karakteristik pendidikan ibu yang mempengaruhi mobilisasi dini pada ibu nifas post Sectio Caesarea di Ruang Merpati RSUD Dr. Soetomo Surabaya; 2)mengidentifikasi karakteristik umur ibu yang mempengaruhi mobilisasi dini pada ibu nifas post Sectio Caesarea di Ruang Merpati RSUD Dr. Soetomo Surabaya ;3)mengidentifikasi karakteristik parietas ibu yang mempengaruhi mobilisasi dini pada ibu nifas post Sectio Caesarea di Ruang Merpati RSUD Dr. Soetomo Surabaya.

\section{BAHAN DAN METODE}

Desain Penelitian ini adalah deksriptif dengan pendekatan cross sectional populasi penelitian adalah semua ibu nifas dengan Sectio Caesarea yang dirawat di Ruang Merpati RSUD Dr. Soetomo Surabaya sejumlah 50 pasien.Sampel penelitian sebesar 30 ibu nifas post Sectio Caesarea, pengambilan sampeldengan teknik quotasampling. Variabel dalam penelitian ini adalah variabel tunggal yaitu mobilisasi dini PostSectio Caesarea.Metode pengumpulan data yang digunakan adalah observasional yang dilakukan oleh peneliti. Dimana peneliti melakukan observasi langsung ke ibu nifas post Sectio Caesarea dan melihat data dari data sekunder yang didapatkan dari rekam medis pasien.

Analisis data dalam penelitian ini menggunakan analisis unvariate atau analisis deskriptif yang bertujuan untuk menjelaskan atau mendeskripsikan karakteristik setiap variabel penelitian. Dalam analisis ini akan menghasilkan distribusi frekuensi dan presentase tiap variabel (Notoatmodjo, 2010). Teknik analisis data yang digunakan adalah cara perhitungan presentase. Aspek yang dinilai menggunakan rumus :

Keterangan :

$$
P=\frac{F}{N} \times 100 \%
$$

$\mathrm{P}=$ persentase

$\mathrm{F}=$ frekuensi

$\mathrm{N}$ = jumlah subjek penelitian atau responden

(Arikunto, 2010)

\section{HASIL DAN PEMBAHASAN}

\section{Karakteristik Responden: \\ Pendidikan}

Tabel.1. Distribusi Frekuensi Pendidikan Ibu Nifas Post Sectio Caesarea Di RSUD dr. Soetomo Surabaya periode 30 April - 26 Mei 2012

\begin{tabular}{lcc}
\hline \multicolumn{1}{c}{ Pendidikan } & Frekuensi & Persentase \\
\hline SD & 8 & 26,7 \\
SMP & 11 & 36,6 \\
SMA & 9 & 30 \\
PT & 2 & 6,7 \\
\hline Jumlah & 30 & 100 \\
\hline
\end{tabular}


Dari Tabel.1. menunjukkan bahwa pendidikan ibu nifas post sectio caesarea terbanyak SMP sebesar 36,6\%. Hal ini disebabkan karena sarana pendidikan semakin banyak dan terjangkau sehingga pendidikan ibu nifas post sectio caesarea semakin tinggi. Semakin tinggi tingkat pendidikan seseorang maka makin mudah menerima informasi dari orang lain maupun dari media masa mereka akan berpikiran maju dan sangat ingin mencoba hal yang baru diperkenalkan (Koentjoroningrat, 1997).

Tingkat pendidikan sesorang tidak selalu mempengaruhi tingkat pengetahuan ibu dalam bidang kesehatan. Tiap individu mempunyai daya pikir yang sama tetapi saat seseorang menerima informasi dari orang lain maka apakah ia langsung menerima atau menyanggahnya. Semakin tinggi tingkat pengetahuan seseorang maka semakin tinggi pula kemampuannya untuk menyanggah pendapat orang lain.

\section{Umur}

Tabel 2. Distribusi Frekuensi Umur lbu Nifas Post Sectio Caesarea Di RSUD dr. Soetomo Surabaya periode 30 April - 26 Mei 2012

\begin{tabular}{lcc}
\hline \multicolumn{1}{c}{ Umur } & Frekuensi & Persentase \\
\hline$<20$ tahun & 4 & 13,3 \\
$20-35$ tahun & 17 & 56,7 \\
$>35$ tahun & 9 & 30 \\
\hline Jumlah & 30 & 100 \\
\hline
\end{tabular}

Dari Tabel.2. menunjukkan bahwa umur ibu nifas post sectio caesarea terbanyak umur antara $20-35$ tahun sebesar $56,7 \%$.

Umur adalah lama hidup individu terhitung mulai saat dilahirkan sampai berulang tahun (Nursalam, 2003). Semakin tua semakin bijaksana, semakin banyak informasi yang dijumpai dan semakin banyak hal yang dikerjakan sehingga menambah pengetahuannya.

Pada usia 20-35 tahun merupakan usia paling baik untuk melahirkan. Banyak faktor yang menyebabkan terjadi proses persalinan yang diakhiri dengan sectio caesarea diantaranya penyakit penyerta dan kelainan panggul yang tidak memungkinkan untuk bersalin secara spontan.

\section{Paritas}

Tabel 3. Distribusi Frekuensi Paritas Ibu Nifas Post Sectio Caesarea Di RSUD dr. Soetomo Surabaya periode 30 April - 26 Mei 2012

\begin{tabular}{lcc}
\hline \multicolumn{1}{c}{ Paritas } & Frekuensi & Persentase \\
\hline Primipara & 6 & 20 \\
Multipara & 14 & 46,7 \\
Grandemulti & 10 & 33,3 \\
\hline Jumlah & 30 & 100 \\
\hline
\end{tabular}

Dari Tabel 3. menunjukkan bahwa paritas ibu nifas post sectio caesarea terbanyak multipara sebesar $46,7 \%$. Paritas adalah keadaan wanita dengan jumlah anak yang pernah dilahirkan. Menurut Notoatmodjo (2005) menjelaskan bahwa pengalaman adalah guru yang baik. Pepatah ini mengandung maksud bahwa pengalaman ini merupakan sumber pengetahuan atau pengalaman merupakan suatu cara memperoleh kebenaran pengetahuan oleh sebab itu pengalaman pribadi dapat digunakan sebagai upaya untuk memperoleh pengetahuan.

\section{Mobilisasi Dini Post sectio caesarea}

Tabel 4. Distribusi Frekuensi Mobilisasi Dini post sectio caesarea latihan pernapasan iga-iga dan latihan gerakan kaki Di RSUD dr. Soetomo Surabaya periode 30 April - 26 Mei 2012

\begin{tabular}{|c|c|c|}
\hline $\begin{array}{c}\text { Mobilisasi dini 6 } \\
\text { jam post SC lathan } \\
\text { pemapasan iga-iga } \\
\text { dan lathan gerakan } \\
\text { kaki }\end{array}$ & Frekuensi & $\begin{array}{c}\text { Persentas } \\
\text { e }\end{array}$ \\
\hline Baik & 15 & 50 \\
\hline Cukup & 13 & 43,4 \\
\hline Kurang & 2 & 6,6 \\
\hline Jumlah & 30 & 100 \\
\hline
\end{tabular}

Dari Tabel.4. menunjukkan bahwa mobilisasi dini 6 jampost sectio caesarea latihan pernapasan iga-iga dan latihan gerakan kaki dapat dilakukan ibu dengan baik sebesar $50 \%$ dan yang melakukan kurang 6,6\%.

Tabel5. Distribusi Frekuensi Mobilisasi Dini 8 jam post sectio caesarea sudah harus miring ke kiri dan ke 
kanan Di RSUD dr. Soetomo Surabaya periode 30 April - 26 Mei 2012

\begin{tabular}{|c|c|c|}
\hline $\begin{array}{c}\text { Mobilisasi dini 8jam post } \\
\text { SC sudah harus miring ke } \\
\text { kiri dankekanan }\end{array}$ & Frekuensi & $\begin{array}{c}\text { Persent } \\
\text { ase }\end{array}$ \\
\hline Baik & 17 & 56,7 \\
\hline Cukup & 7 & 23,3 \\
\hline Kurang & 6 & 20 \\
\hline Jumlah & 30 & 100 \\
\hline
\end{tabular}

Dari Tabel 5. menunjukkan bahwa mobilisasi dini 8 jam post sectio caesarea sudah harus miring ke kiri dan ke kanan dapat dilakukan ibu dengan baik sebesar 56,7\% dan yang melakukan kurang $20 \%$.

Tabel 6. Distribusi Frekuensi Mobilisasi Dini 24 jam pertama post sectio caesarea harus bisa duduk Di RSUD dr. Soetomo Surabaya periode 30 April 26 Mei 2012

\begin{tabular}{|c|c|c|}
\hline $\begin{array}{c}\text { Mobilisasi dini 24 jam } \\
\text { pertama post sectio } \\
\text { caesarea harus bisa duduk }\end{array}$ & Frekuensi & $\begin{array}{c}\text { Persent } \\
\text { ase }\end{array}$ \\
\hline Baik & 21 & 70 \\
\hline Cukup & 8 & 26,7 \\
\hline Kurang & 1 & 3,3 \\
\hline Jumlah & 30 & 100 \\
\hline
\end{tabular}

Dari Tabel 6. menunjukkan bahwa mobilisasi dini 24 jam pertama post sectio caesarea harus bisa duduk dapat dilakukan ibu dengan baik sebesar $70 \%$ dan yang melakukan kurang 3,3\%.

Tabel 7. Distribusi Frekuensi Mobilisasi Dini Hari ke 2 post sectio caesarea harus bisa berdiri Di RSUD dr. Soetomo Surabaya periode 30 April - 26 Mei 2012

\begin{tabular}{|c|c|c|}
\hline $\begin{array}{c}\text { Mobilisasi dini hari ke2 } \\
\text { post sectio caesarea } \\
\text { hanus bisaberdiri }\end{array}$ & Frekuensi & $\begin{array}{c}\text { Persent } \\
\text { ase }\end{array}$ \\
\hline Baik & 26 & 86,7 \\
\hline Cukup & 4 & 13,3 \\
\hline Kurang & - & - \\
\hline Jumlah & 30 & 100 \\
\hline
\end{tabular}

Dari Tabel 7. menunjukkan bahwa mobilisasi dini hari ke 2 post sectio caesarea hanus bisa berdiri dapat dilakukan ibu dengan baik sebesar $86,7 \%$ dan tidak ada yang melakukan kurang.
Tabel 8. Distribusi Frekuensi Mobilisasi Dini Hari ke 3 post sectio caesarea harus bisa berjalan Di RSUD dr. Soetomo Surabaya periode 30 April - 26 Mei 2012

\begin{tabular}{|c|c|c|}
\hline $\begin{array}{c}\text { Mobilisasi dini hari ke } \\
3 \text { post sectio caesarea } \\
\text { hanus bisa berjalan }\end{array}$ & Frekuensi & Persentase \\
\hline Baik & 26 & 86,7 \\
\hline Cukup & 4 & 13,3 \\
\hline Kurang & - & - \\
\hline Jumlah & 30 & 100 \\
\hline
\end{tabular}

Dari Tabel 8. menunjukkan bahwa mobilisasi dini hari ke 3 post sectio caesarea harus bisa berjalan dapat dilakukan ibu dengan baik sebesar $86,7 \%$ dan tidak ada yang melakukan kurang.

Tabel 9. Distribusi Frekuensi Mobilisasi Dini Ibu Nifas Post Sectio Caesarea Di RSUD dr. Soetomo Surabaya periode 30 April - 26 Mei 2012

\begin{tabular}{|c|c|c|c|c|c|c|c|c|}
\hline \multirow{3}{*}{$\begin{array}{l}\text { Mobilisa } \\
\text { si dini }\end{array}$} & \multicolumn{6}{|c|}{ Mobilisasi dini } & \multirow{2}{*}{\multicolumn{2}{|c|}{ Jumlah }} \\
\hline & \multicolumn{2}{|c|}{ Baik } & \multicolumn{2}{|c|}{ Cukup } & \multicolumn{2}{|c|}{$\begin{array}{c}\text { Kuran } \\
\mathrm{g}\end{array}$} & & \\
\hline & $\Sigma$ & $\%$ & $\Sigma$ & $\%$ & $\Sigma$ & $\%$ & $\Sigma$ & $\%$ \\
\hline $\begin{array}{l}6 \text { jam post } \\
\text { SC latihan } \\
\text { pernapas } \\
\text { an iga-iga } \\
\text { dan } \\
\text { latihan } \\
\text { gerakan } \\
\text { kaki }\end{array}$ & 15 & 50 & 13 & $\begin{array}{c}43 \\
4\end{array}$ & 2 & $\begin{array}{l}6 \\
6\end{array}$ & 30 & 100 \\
\hline $\begin{array}{l}8 \text { jam post } \\
\text { SC sudah } \\
\text { harus } \\
\text { miring ke } \\
\text { kin dan ke } \\
\text { kanan }\end{array}$ & 17 & $\begin{array}{c}56 \\
7\end{array}$ & 7 & $\begin{array}{c}23 \\
3\end{array}$ & 6 & $\begin{array}{l}2 \\
0\end{array}$ & 30 & 100 \\
\hline $\begin{array}{l}24 \text { jam } \\
\text { pertama } \\
\text { post Sc } \\
\text { harus bisa } \\
\text { duduk }\end{array}$ & 21 & 70 & 8 & $\begin{array}{c}26 \\
7\end{array}$ & 1 & $\begin{array}{l}3, \\
3\end{array}$ & 30 & 100 \\
\hline $\begin{array}{l}\text { Hari ke } 2 \\
\text { post SC } \\
\text { harus bisa } \\
\text { berdiri }\end{array}$ & 26 & $\begin{array}{c}86 \\
7\end{array}$ & 4 & $\begin{array}{c}13 \\
3\end{array}$ & - & - & 30 & 100 \\
\hline $\begin{array}{l}\text { Hari ke } 3 \\
\text { post SC } \\
\text { harus bisa } \\
\text { berjalan }\end{array}$ & 26 & $\begin{array}{c}86 \\
7\end{array}$ & 4 & $\begin{array}{c}13 \\
3\end{array}$ & - & - & 30 & 100 \\
\hline
\end{tabular}


Dari Tabel.9. menunjukkan bahwa mobilisasi dini ibu nifas post sectio caesarea dengan baik terjadi pada hari ke 2 dan hari ke 3 Post Sectio Caesarea sebesar 86,7\%. Menurut Manuaba (2010) mobilisasi dini ialah kebijaksanaan untuk selekas mungkin membimbing penderita keluar dari tempat tidurnya dan membimbingnya selekas mungkin untuk berjalan. Mobilisasi fisik setelah sadar pasien boleh miring berikutnya duduk bahkan berjalan-jalan dengan infus, infus dengan cateter dibuka pada hari kedua atau ketiga.

Mobilisasi dini bertujuan agar ibu cepat pulih kembali seperti keadaan semula dan dapat beraktivitas secara mandiri tanpa bergantung pada orang lain. Mobilisasi dini juga dapat membantu mempercepat pemulihan ibu nifas setelah dilakukan sectio caesarea.

Tabulasi Silang Karakteristik terhadap Mobilisasi Dini Ibu Nifas Post Sectio Caesarea Di RSUD dr. Soetomo Surabaya

Tabel 10. Tabulasi Silang antara Pendidikan Ibu Nifas dengan Mobilisasi Dini lbu Nifas Post Sectio Caesarea Di RSUD dr. Soetomo

\begin{tabular}{|c|c|c|c|c|c|c|c|c|}
\hline \multirow{3}{*}{$\begin{array}{l}\text { Pendi } \\
\text { dikan }\end{array}$} & \multicolumn{6}{|c|}{ Mobilisasi Dini } & \multirow{3}{*}{$\Sigma$} & \multirow{3}{*}{$\begin{array}{c}\text { Per } \\
\text { sen } \\
\text { tas } \\
\mathrm{e}\end{array}$} \\
\hline & \multicolumn{2}{|c|}{ Baik } & \multicolumn{2}{|c|}{ Cukup } & \multicolumn{2}{|c|}{$\begin{array}{c}\text { Kuran } \\
\mathrm{g}\end{array}$} & & \\
\hline & $\Sigma$ & $\%$ & $\Sigma$ & $\%$ & $\Sigma$ & $\%$ & & \\
\hline SD & 7 & $\begin{array}{c}87 \\
5\end{array}$ & 1 & $\begin{array}{c}12 \\
5\end{array}$ & - & - & 8 & 100 \\
\hline SMP & 5 & $\begin{array}{c}45 \\
4\end{array}$ & 3 & $\begin{array}{c}27 \\
3\end{array}$ & 3 & $\begin{array}{r}27 \\
3\end{array}$ & 11 & 100 \\
\hline SMA & 5 & $\begin{array}{c}55, \\
6\end{array}$ & 3 & $\begin{array}{c}33, \\
3\end{array}$ & 1 & $\begin{array}{l}11 \\
1\end{array}$ & 9 & 100 \\
\hline PT & 1 & 50 & 1 & 50 & - & - & 2 & 100 \\
\hline $\begin{array}{c}\text { Jumla } \\
\mathrm{h}\end{array}$ & 18 & & 8 & & 4 & & 30 & \\
\hline
\end{tabular}

Surabaya periode 30 April - 26 Mei 2012

Dari Tabel 10. menunjukkan bahwa dilihat dari tingkat pendidikan ibu nifas post sectio caesarea di Ruang Merpati RSUD dr. Soetomo Surabaya yang melakukan mobilisasi dini post sectio caesarea dengan baik menunjukkan 87,5\% berpendidikan SD dan yang berpendidikan SMA menunjukkan $11,1 \%$ melakukan mobilisasi dini post sectio caesarea dengan kurang.

Tabel 11. Tabulasi Silang antara Umur Ibu Nifas dengan Mobilisasi Dini lbu Nifas Post Sectio Caesarea Di RSUD dr. Soetomo Surabaya periode 30 April - 26 Mei 2012

\begin{tabular}{|c|c|c|c|c|c|c|c|c|}
\hline \multirow{3}{*}{ Umur } & \multicolumn{6}{|c|}{ Mobilisasi Dini } & \multirow{3}{*}{$\Sigma$} & Per \\
\hline & \multicolumn{2}{|c|}{ Baik } & \multicolumn{2}{|c|}{ Cukup } & \multicolumn{2}{|c|}{$\begin{array}{c}\text { Kuran } \\
\mathrm{g}\end{array}$} & & $\begin{array}{l}\text { sen } \\
\text { tas }\end{array}$ \\
\hline & $\Sigma$ & $\%$ & $\Sigma$ & $\%$ & $\Sigma$ & $\%$ & & e \\
\hline $\begin{array}{c}<20 \\
\text { tahun }\end{array}$ & 2 & 50 & 2 & 50 & - & - & 4 & 100 \\
\hline $\begin{array}{l}20-35 \\
\text { tahun }\end{array}$ & 10 & $\begin{array}{c}58, \\
9\end{array}$ & 4 & $\begin{array}{c}23, \\
5\end{array}$ & 3 & $\begin{array}{c}17, \\
6\end{array}$ & $\begin{array}{l}1 \\
7\end{array}$ & 100 \\
\hline $\begin{array}{l}>35 \\
\text { tahun }\end{array}$ & 6 & $\begin{array}{c}66 \\
7\end{array}$ & 2 & $\begin{array}{c}22, \\
2\end{array}$ & 1 & $\begin{array}{c}11, \\
1\end{array}$ & 9 & 100 \\
\hline $\begin{array}{c}\text { Jumla } \\
\mathrm{h}\end{array}$ & 18 & & 8 & & 4 & & $\begin{array}{l}3 \\
0\end{array}$ & \\
\hline
\end{tabular}

Dari Tabel 11. menunjukkan bahwa dilihat dari umur ibu nifas post sectio caesarea di Ruang Merpati RSUD dr. Soetomo Surabaya yang melakukan mobilisasi dini post sectio caesarea dengan baik menunjukkan $66,7 \%$ berumur $>35$ tahun dapat melakukan mobilisasi dini post sectio caesarea dengan baik dan yang berumur >35 tahun menujukkan $11,1 \%$ melakukan mobilisasi dini post sectio caesarea dengan kurang. Dapat disimpulkan bahwa semakin bertambah umur mobilisasi dini dilakukan lebih baik.

Tabel 12. Tabulasi Silang antara paritas Ibu Nifas dengan Mobilisasi Dini lbu Nifas Post Sectio Caesarea Di RSUD dr. Soetomo Surabaya periode 30 April - 26 Mei 2012

\begin{tabular}{|l|c|c|c|c|c|c|c|c|}
\hline \multirow{4}{*}{ Paritas } & \multicolumn{6}{|c|}{ Mobilisasi Dini } & \multirow{2}{*}{ Baik } & \multicolumn{2}{|c|}{ Cukup } & \multicolumn{2}{|c|}{$\begin{array}{c}\text { Kuran } \\
\text { g }\end{array}$} & \multirow{2}{*}{$\Sigma$} & $\%$ \\
\cline { 2 - 9 } & $\Sigma$ & $\%$ & $\Sigma$ & $\%$ & $\Sigma$ & $\%$ & \\
\hline Primipara & 2 & $\begin{array}{l}33, \\
3\end{array}$ & 2 & $\begin{array}{l}33, \\
3\end{array}$ & 2 & $\begin{array}{l}33, \\
3\end{array}$ & 6 & 100 \\
\hline Multipara & 10 & $\begin{array}{l}71, \\
4\end{array}$ & 3 & $\begin{array}{l}21, \\
4\end{array}$ & 1 & 7,1 & 14 & 100 \\
\hline $\begin{array}{l}\text { Grande } \\
\text { multi }\end{array}$ & 6 & 60 & 3 & 30 & 1 & 10 & 10 & 100 \\
\hline Jumlah & 18 & & 8 & & 4 & & 30 & \\
\hline
\end{tabular}


Dari Tabel 12. menunjukkan bahwa dilihat dari paritas ibu nifas post sectio caesarea di Ruang Merpati RSUD dr. Soetomo Surabaya yang melakukan mobilisasi dini post sectio caesarea dengan baik menunjukkan $71,4 \%$ pada paritas multipara dan pada grandemulti menujukkan $10 \%$ melakukan mobilisasi dini post sectio caesarea dengan kurang.

Karakteristik yang Mempengaruhi Mobilisasi Dini pada Ibu Nifas Post Sectio Caesarea terhadap Pendidikan

Dari Tabel 10. menunjukkan bahwa tingkat pendidikan ibu nifas post sectio caesarea dengan mobilisasi dini post sectio caesarea di Ruang Merpati RSUD dr. Soetomo Surabaya, cenderung dilakukan dengan baik pada tingkat pendidikan SD sebesar $87,5 \%$. Latar belakang pendidikan ibu membantu dalam penerimaan informasi dari orang lain atau petugas kesehatan dan kesadarannya untuk melakukan mobilisasi dini post sectio caesarea. Pada kenyataannya saat peneliti mengadakan penelitian di Ruang Merpati RSUD dr. Soetomo Surabaya bahwa yang berpendidikan SD atau rendah lebih berani melakukan mobilisasi dini post sectio caesarea karena keterbatasan pengetahuan dan pemikiran sehingga apa yang diarahkan oleh petugas pelayanan kesehatan selalu langsung dituruti dan dilaksanakan jadi tidak selalu berhubungan bahwa semakin tinggi pendidikan seseorang maka semakin mudah menerima informasi dari orang lain maupun media masa. Mereka akan berpikiran maju dan sangat ingin mencoba hal yang baru diperkenalkan (Koentjoroningrat, 1997)

\section{Karakteristik yang Mempengaruhi Mobilisasi Dini pada Ibu Nifas Post Sectio Caesarea terhadap Umur}

Dari Tabel 11. menunjukkan bahwa umur ibu nifas post sectio caesarea dengan mobilisasi dini post sectio caesarea di Ruang Merpati RSUD dr. Soetomo Surabaya, cenderung dilakukan dengan baik pada ibu umur $>35$ tahun sebesar $66,7 \%$.

Umur dapat mencerminkan pengalaman dan kematangan jiwanya dalam kemampuan berfikir kreatif, pada kenyataannya saat peneliti mengadakan penelitian di Ruang Merpati RSUD dr. Soetomo Surabaya hasil penelitian menunjukkan bahwa pada umur $>35$ tahun ibu lebih mampu untuk melakukan mobiliasi dini post sectio caesarea. Hal tersebut sedah sesuai dengan teori bahwa semakin tua semakin bijaksana, semakin banyak informasi yang dijumpai dan semakin banyak hal yang dikerjakan sehingga menambah pengetahuannya (Nursalam, 2003).

\section{Karakteristik yang Mempengaruhi Mobilisasi Dini pada Ibu Nifas Post Sectio Caesarea terhadap Paritas}

Dari Tabel 12. menunjukkan bahwa paritas ibu nifas post sectio caesarea dengan mobilisasi dini post sectio caesarea di Ruang Merpati RSUD dr. Soetomo Surabaya, cenderung dilakukan dengan baik pada ibu multipara sebesar $74,4 \%$. Pada kenyataannya saat peneliti mengadakan penelitian di Ruang Merpati RSUD dr. Soetomo Surabaya hasil penelitian menunjukkan bahwa ibu dengan multipara lebih berani melakukan mobilisasi dini post sectio caesarea karena pengalaman ibu yang pernah melahirkan maka ibu mampu untuk melakukan mobilisasi dini lebih cepat. Pada ibu primipara dan grandemulti ada gangguan untuk melakukan mobilisasi dini post sectio caesarea.

\section{SIMPULAN DAN SARAN}

Simpulan dari penelitianKarakteristik yang Mempengaruhi Mobilisasi Dini pada Ibu Nifas Post Sectio Caesarea di Ruang Merpati RSUD Dr. Soetomo Surabaya 2012 sebagai berikut:

1)Tingkat pendidikan ibu nifas post sectio caesarea di Ruang Merpati RSUD dr. Soetomo Surabaya yang melakukan mobilisasi dini post sectio caesarea dengan baik menunjukkan $87,5 \%$ berpendidikan SD dan yang berpendidikan SMA menunjukkan $11,1 \%$ melakukan mobilisasi dini post sectio caesarea dengan kurang.

2) Umur ibu nifas post sectio caesarea di Ruang Merpati RSUD dr. Soetomo Surabaya yang melakukan mobilisasi dini post sectio caesarea dengan baik menunjukkan $66,7 \%$ berumur $>35$ tahun dapat melakukan 
mobilisasi dini post sectio caesarea dengan baik dan yang berumur >35 tahun menujukkan $11,1 \%$ melakukan mobilisasi dini post sectio caesarea dengan kurang.

3) Paritas ibu nifas post sectio caesarea di Ruang Merpati RSUD dr. Soetomo Surabaya yang melakukan mobilisasi dini post sectio caesarea dengan baik menunjukkan $71,4 \%$ pada paritas multipara dan pada grandemulti menujukkan $10 \%$ melakukan mobilisasi dini post sectio caesarea dengan kurang.

Berdasarkan hasil penelitian maka disarankan:Bagi petugas kesehatan

harus membimbing ibu post sectio caesarea untuk dapat segera melakukanmobilisasi dini dengan benar

\section{DAFTAR ACUAN}

Arifin, Z. (2010). Metodologi Penelitian Pendidikan Filosofi, Teori dan Aplikasinya. Surabaya : Lentera Cendikia.

Arikunto, S. (2010). Prosedur Penelitian Suatu Pendekatan Praktek. Jakarta: Rineka Cipta.

Bobak, dkk. (2005). Buku Ajar Keperawatan Maternitas. Jakarta : EGC.

Depkes RI. (2008). Profil Kesehatan Provinsi Jawa Timur 2008. Selasa Maret 2012. http://www.depkes.go.id.

$\begin{array}{ll} & \\ \text { 2007. } & \text { (2007). Profil Kesehatan Indonesia } \\ \text { http://www.depkes.go.id. }\end{array}$

Derek, dkk. (2005). Setiap Wanita. Jakarta : Delaprasta Publishing.

Hidayat, AAA. (2007). Metode Penelitian Kebidanan Teknik Analisis Data. Jakarta : Salemba Medika

Notoatmodjo, S. (2008). IImu Kesehatan Masyarakat. Jakarta : Rineka Cipta.
(2010). Metodologi Penelitian Kesehatan. Jakarta: Rineka Cipta. (2010). Promosi Kesehatan Teori dan Aplikasi. Jakarta : Rineka Cipta.

(2007). Promosi Kesehatan Teori dan IImu Perilaku. Jakarta : Rineka Cipta.

Kasdu, D. (2003). Operasi Caesar: Masalah dan Solusinya. Jakarta: Puspa Swara.

Manuaba, IBG. (2010). IImu Kebidanan, Penyakit Kandungan, dan Keluarga Berencana untuk Pendidikan Bidan. Jakarta : EGC.

\section{(1999). Operasi Kebidanan,} Kandungan, dan Keluarga Berencana untuk Dokter Umum. Jakarta: EGC.

Maryunani, A. (2009). Asuhan pada lbu dalam Masa Nifas (Postpartum). Jakarta : Trans Info Media.

Mochtar, R. (1998). Sinopsis Obstetri: Obstetri Operatif, Obstetri Sosial Ed. 2, Jilid 2. Jakarta : EGC

Nursalam. (2007). Manajemen Keperawatan. Jakarta: Salemba Medika.

(2011). Konsep dan Penerapan Metodologi Penelitian IImu Keperawatan. Jakarta: Salemba Medika.

Widayatun, TR. (1999). Ilmu Perilaku. Jakarta : Sagung Seto

Widuri, H. (2010). Kebutuhan Dasar Manusia (Aspek Mobilitas dan Istirahat Tidur). Yogyakarta : Gosyen Publishing. 